\title{
Teacher Professional Development in Language-Driven CLIL: A Case Study
}

El desarrollo profesional para AICLE enfocado en la lengua:

242 Un estudio de caso

O desenvolvimento profissional no CLIL com foco no idioma:

Um estudo de caso

Darío Luis BANEGAS

University of Strathclyde, United Kingdom dario.banegas@strath.ac.uk https://orcid.org/0000-0003-0225-0866

Received: 05/02/2019

Accepted by peers: 09/04/2019
Sent to peer review: 04/03/2019 Approved: 23/04/2019

DOI: 10.5294/laclil.2019.12.2.3

To reference this article (APA) / Para citar este artículo (APA) / Para citar este artigo (APA) Banegas, D. L. (2019). Teacher professional development in language-driven CLIL: A case study. Latin American Journal of Content \& Language Integrated Learning, 12(2), 242-264. DOI: https://doi.org/10.5294/laclil.2019.12.2.3 
ABSTRACT. The professional development of and language integrated learning (CLIL) continues to be a niche in the language education literature, particularly in Latin America. The aim of this study is to explore the effects of a continuing professional development course delivered in 2018 to support language-driven CLIL implementation in state secondary schools in Argentina. Built as a case study, the investigation draws on data from one teacher collected through multiple sources for triangulation purposes. Two research questions guided the study: 1) What beliefs does a teacher have of language-driven CLIL? and 2) What are the effects of a continuing professional development course on language-driven CLIL targeted at EFL secondary school teachers? Findings show that authenticity, rather than language-content integration, is a salient feature of language-driven CLIL in this teacher's practice. Findings also reveal that CLIL success depends on learners' English language proficiency. Drawing on its teacher's beliefs of CLIL, the course had an impact on the teacher's identity as a materials developer and autonomous and critical practitioner who could theorize by reflecting on her practices and the readings provided by the course tutor.

Keywords (Source: Unesco Thesaurus): Language-driven CLIL; professional development; career development; authenticity; collaboration; structured learning; beliefs.

RESUMEN. El desarrollo profesional en AICLE continúa siendo un nicho en la literatura sobre educación en lenguas en América Latina. El presente estudio tiene como objetivo explorar los efectos de un curso de formación docente continua brindado en 2018 para acompañar la implementación de AICLE con foco en la lengua en escuelas estatales secundarias en Argentina. Dos preguntas guiaron el estudio: 1) ¿Qué creencias sobre AICLE con foco en la lengua tienen los profesores de inglés?, y 2) ¿Cuáles son los efectos de un curso de formación docente continua sobre AICLE con foco en la lengua en un grupo de profesores de inglés para la escuela secundaria? Presentado como un estudio de caso, la investigación remite a datos de una docente recolectados a través de múltiples fuentes con fines de triangulación. Los resultados muestran que la autenticidad, más que la integración de lengua y contenido, es una característica destacada de AICLE. Los resultados también demuestran que el éxito de AICLE depende del nivel de competencia en inglés que posean los estudiantes. Con base en las percepciones de la docente como caso, el curso produjo un impacto positivo en la identidad de la docente como desarrolladora de materiales, y como docente crítica y autónoma capaz de teorizar sus prácticas a partir de la reflexión y la lectura de material.

Palabras clave (Fuente: tesauro de la Unesco): AICLE enfocado en la lengua; desarrollo profesional; desarrollo de la carrera; autenticidad; colaboración; aprendizaje estructurado; creencias.

RESUMO. O desenvolvimento profissional no CLIL continua sendo um espaço não preenchido na literatura sobre ensino de idiomas na América Latina. O presente estudo tem como objetivo explorar os efeitos de um curso contínuo de treinamento de professores oferecido em 2018 para acompanhar a implementação do CLIL com foco em idiomas nas escolas secundárias estaduais da Argentina. Duas perguntas orientaram o estudo: 1) Quais crenças sobre o CLIL com foco no idioma os professores de inglês têm? E 2) Quais são os efeitos de um curso contínuo de treinamento de professores no CLIL com foco no idioma em um grupo de professores de inglês para o ensino médio? Apresentada como um estudo de caso, a pesquisa refere-se a dados de uma professora coletados por várias fontes para fins de triangulação. Os resultados mostram que a autenticidade, ao invés da integração de linguagem e conteúdo, é uma característica proeminente do CLIL. Os resultados também mostram que o sucesso do CLIL depende do nível de proficiência em inglês que os alunos possuem. Com base nas percepções do professor como um caso, o curso teve um impacto positivo na identidade do professor como desenvolvedor de materiais e como professor crítico e autônomo, capaz de teorizar suas práticas a partir da reflexão e leitura do material.

Palavras-chave (Fonte: tesauro da Unesco): CLIL focado na linguagem; desenvolvimento profissional; desenvolvimento de carreira; autenticidade; colaboração; aprendizado estruturado; crenças. 


\section{Introduction}

It is undeniable that Content and Language Integrated Learning (CLIL) is thriving as it is embraced by schools and educational systems around the world in a concerted effort to create opportunities for synthesis and holistic learning. This claim rests on recent publications attesting to CLIL's impressive growth in large parts of Europe (Coral, Lleixà, \& Ventura, 2018; Mahan, Brevik, \& Ødegaard, 2018; Navarro-Pablo \& García-Jiménez, 2018; Martínez-Agudo, 2019; Merino \& Lasagabaster, 2018; Pérez-Cañado, 2018a, 2018b; San Isidro, 2018) and steady increase in Latin America (Argudo, Abad, Fajardo-Dack, \& Cabrera, 2018; Banegas, 2018; Garzón-Díaz, 2018; Keogh, 2017; McDougald, 2015; Pimentel-Siqueira, Landau, \& Alburquerque-Paraná, 2018).

In South America, CLIL is taking a particular form. In a review article about CLIL in this area, Pimentel-Siqueira et al. (2018) state that CLIL has moved beyond supplementary forms in ELT (Ioannou-Georgiou, 2012) "by strengthening its connections with general educational theories [...] through a focus on the learners' development and construction of knowledge by means of a dialogic relationship with their peers, their teacher, and materials" (p. 196). In this quote, the authors highlight the socio-constructivist and integrative nature of CLIL. Pimentel-Siqueira et al. (2018) add that aspects related to language learning and proficiency, culture, and identity are taking special features given how locally produced materials, teacher preparation, and CLIL expansion are addressed by teachers, school administrators, and specialists. According to a recent review (Banegas, Poole, \& Corrales, in press), in many South American educational institutions, CLIL has been mostly included through a language-driven perspective where CLIL lessons are in the hands of foreign language teachers while the emphasis is on language learning through school content. In other words, curricular content becomes the conduit for meaningful and motivating foreign language learning. For example, Banegas (2013) carried out a study with secondary-school learners in Argentina and found that CLIL in English as a foreign language (EFL) lessons may be adopted as an approach to enhance motivation and allow learners to see education as a context-embedded, relevant and meaningful activity. 
While (language-driven) CLIL has expanded through South America, tertiary and university teacher training as concomitant of successful CLIL implementation lags behind (Banegas et al., in press). Therefore, there is a pressing need for systematic pre-service and continuing in-service professional development. The aim of this article is to understand the impact of a professional development initiative carried out with EFL teachers in state secondary schools in a southern Argentinian province. This article concentrates on one teacher's journey towards CLIL professional development. The following research questions guided this study:

1. What beliefs does an EFL teacher hold concerning language-driven CLIL?

2. What experiences does this EFL teacher undergo during a continuing professional development course on language-driven CLIL?

It should be noted that the term beliefs is understood as a dimension of teacher cognition. Teacher beliefs, for its part, refers to a teacher's convictions, judgements, attitudes, and values based on situated experiences (Borg, 2006).

In the sections below, I put forward a literature review at the intersection of CLIL pedagogy and teacher development, as well as a detailed description and analysis of the teacher under study. The article discusses implications for research and practice.

\section{Literature Review}

Ball, Kelly, and Clegg (2015) stress that, in CLIL programs, learners are driven to develop their literacy and cognitive skills by engaging in curricular content supported by language learning strategies that make the content accessible. However, they are cautious about EFL proficiency in CLIL, as they state that, because of the authentic nature of sources and content complexity involved, CLIL is meaningful and possible with learners and teachers who are already proficient in the foreign language. The authors insist that, provided learners are at advanced stages in their language learning development, they can acquire new content that can also contribute to their school trajectory in L1. They can also develop academic language skills to function in bilingual ed- 
ucation or education where a foreign language is a requirement. Notwithstanding, this view may not be inclusive of other practices where learners hold limited proficiency in English (Garzón-Díaz, 2018). What is central in the learning process, with all kinds of proficiency levels, is that the materials and activities learners are required to handle are authentic to the curriculum.

Authenticity is a major feature of CLIL implementation and materials development. Pinner (2013) takes a broad perspective on authenticity in CLIL and suggests that

Authenticity within CLIL is more directly associated with purpose, with reasons for engagement. The authentic texts used in a CLIL classroom are not merely collections of vocabulary and grammar from the TL culture, taken out of one context and placed onto another for language learning. Authenticity in CLIL is something much bigger, directly related with the student and his or her immediate learning goals. Authenticity is directly related to the purpose for being in the classroom, the learning aims and outcomes of the entire curriculum, and more broadly something that will allow learners, hopefully, to take part in the wider discussion as members of a plurilingual society. (p. 47)

In this quote, Pinner (2013) stresses authenticity of purpose. He elaborates on how authenticity should aim at creating meaningful and relevant activities in education, where education is embedded in the sociocultural practices of any given society. While key concepts such as authenticity, functional grammar, cognitive skills, scaffolding language learning, materials development, and motivation are recurrent key pillars in CLIL architecture (Ball et al., 2015; Coyle, Hood, \& Marsh, 2010; Llinares \& Morton, 2017), CLIL literature has been unequivocal about the need to provide teachers with careful and context-responsive support in the shape of continuing professional development courses to manage such key concepts (Pérez-Cañado, 2018c). In the present case study, professional development is a process driven by intrinsic (e.g., broadening personal knowledge and skills) and extrinsic (e.g., obtaining a pay rise) motivation (Avidou-Ungar, 2016). Professional development becomes effective when it encourages teacher reflection based on past and present experiences; structured learning that leads to student learning outcomes; and updated knowledge and skills through autonomous and collaborative work (Cirocki \& Farrell, 2017; Darling-Ham- 
mond, Hyler, \& Gardner, 2017; de Vries, Jansen, \& van de Grift, 2013). According to Coyle, Hood, and Marsh (2010), professional development is critical in securing CLIL success, and they highlight that

without serious attention being paid to implementing strategies for training the professional workforce, which include longer-term plans for skilling multilingual teachers, then quality CLIL is not sustainable. Indeed, it could be said that poor-quality CLIL could contribute to a "lost generation" of young people's learning [...]. Teacher education in CLIL at both pre- and in-service levels needs to involve a range of programmes which address a wide range of CLIL training needs. (pp. 161-162)

Coyle et al.'s (2010) suggestion reinforces the need to conceive CLIL teacher education as an inherent part of CLIL curriculum development and implementation. In light of this requirement, Ball et al. (2015) propose a finer list of five "variables" (p. 268) to secure successful and sustainable CLIL teacher development. The first variable involves CLIL teacher development tailored to meet contextual demands and whether it is embedded in pre-service or in-service teacher education. The second focuses on the extent to which CLIL teacher education should be descriptive or prescriptive. The third aims at increasing teachers' English language proficiency. The fourth reinforces pedagogical skills, not only for language teaching but also for content teaching. Finally, the fifth encourages methodological awareness for developing appropriate and informed pedagogies. In alignment with these variables, Pérez-Cañado (2018c) puts forward a list of CLIL teacher competences: linguistic, pedagogical, scientific knowledge, organizational, interpersonal and collaborative, and reflective and developmental. The author adds that, among other potential solutions for CLIL teacher development, institutions should offer tailor-made courses for in-service teachers based on a careful analysis of the needs and identified variables.

Concerning CLIL teacher development in South America, Banegas et al. (in press) have so far been able to identify only three studies that illustrate how continuing professional development could be supported for CLIL success. For example, in two separate studies, Pistorio (2009) and Hillyard (2011) stress the need to equip language and content teachers with effective tools for integrating curriculum and language learning strategies in ways which are context-responsive and aligned with institutional needs and local demands. In line with these sugges- 
tions, Banegas (2016) reports the outcomes of a workshop with secondary school English language teachers in Argentina in which the focus was on teacher-made CLIL materials. Drawing on the teachers' developed materials, findings show that teachers developed professionally as they engaged in the inclusion of multimodal sources, text simplification, text enhancement through the inclusion of visual support, knowledge structuring through graphic organizers, promotion of cooperative learning strategies, and designing activities for lower-order thinking skills.

While the articles above provide evidence of the positive outcomes of short continuing professional development courses for CLIL, there is a lacuna of studies that examine the impact of professional development based on longer projects in South America (Banegas, 2020; Darwin \& Barahona, 2019). To this effect, the aim of this investigation is to report the outcomes of a four-month in-service teacher development course with secondary school EFL teachers in Chubut, Argentina. In this publication, a case study approach is adopted with the objective of understanding a teacher's trajectory, including beliefs and professional development.

\section{Research Methodology}

Within a qualitative research paradigm, this study has adopted a case study methodology. Yin (2014) defines a case study as "an empirical inquiry that investigates a contemporary phenomenon (the 'case') in depth and within its real-world context" (p. 16). According to Ritchie and Lewis (2003), a case study is built upon only one selected case, which could be a person, a group, or an institution. In this article, one EFL teacher constitutes the "case," which is detailed and intensive and studied in context through more than one data collection method. In the following sections, I describe the context and participants, as well as the data collection instruments, and procedures.

\section{Context and participants}

The participant teacher was involved in a larger project through which a group of 25 EFL teachers voluntarily signed up for a continuing pro- 
fessional development course on language-driven CLIL in Chubut, a province in southern Argentina. The aim of the course was to equip teachers with concepts and tools to design their syllabus, plan and deliver lessons, and develop materials from a language-driven CLIL perspective to invigorate their EFL teaching practices in state secondary education. The course was four-months long and it combined workshops, seminars, and planning, and lessons were delivered through peer teaching or independently (independent teaching included peer or course tutor observation).

In this study, I focus on Claudia (pseudonym). Her selection as a case was based on the following individual teacher characteristics she possesses, which I was interested in studying: 1) She holds an ELT degree from an Argentinian university and has completed other courses on curriculum development; 2) she has taught EFL in state secondary schools since 2003; 3) she has been involved in interinstitutional projects and pre-service English language teacher education as a school-based co-tutor for student-teachers' practicum experience; and 4) she was the only one who completed all the course requirements and obtained the highest passing mark. These four characteristics made Claudia a relevant case because these are the features usually expected to from teachers in ministerial reports and dossiers in Chubut.

\section{Instruments and procedures for data collection}

The following instruments were used to collect data:

- Tutor notes during each session: Notes on teachers' comments, attitudes and behaviors were recorded without any a priori categories. The notes concentrated on the emerging indicators of teachers' professional development.

- Claudia's journal: As part of the course tasks, Claudia recorded her perceptions and experiences related to reading the course material, planning, and implementing her lessons. Her journal contained 35 entries covering the entire duration of the course.

- Claudia's lesson plans and printed self-made materials: She produced 11 lessons plans (for an example, see Appendix) with accompanying materials. 
- Classroom observations on Claudia's lessons: For the purposes of the course, Claudia taught 11 two-hour lessons in a group of twenty-three secondary school learners aged 15-16. She was observed four times: twice by an experienced colleague also attending the course (Lessons 1 and 3) and twice by me (Lessons 6 and 11). Observations focused on the extent to which the lessons could be delivered as planned and on a record of modifications introduced while delivering the lessons.

- Monthly interviews with Claudia: I interviewed Claudia in Spanish four times at the school where she worked. Each interview lasted approximately 40 minutes and focused on the formative feedback she received from her lesson plans, reflections on professional development, and opportunities and challenges she encountered during language-driven CLIL implementation. The interviews were semi-structured and orthographically transcribed for analysis.

Given the qualitative nature of the study, interpretive approach techniques (Hawker \& Kerr, 2016; Payne, 2016) were employed for data analysis. The data collected were subjected to the following process: 1) repeated reading; 2) initial open coding and saturation; 3) axial coding; and 4) theoretical coding for data synthesis.

\section{Findings and discussion}

In light of the literature review condensed in this article, this section offers an interpretation of the categories identified during data analysis in connection to the two research questions.

\section{Language-driven CLIL: beliefs}

In response to the first research question, Claudia's belief of CLIL as an approach to be implemented with learners who exhibit a higher level of English proficiency is connected to the possibilities that the approach offers for authenticity and interdisciplinarity. Her beliefs of language-driven CLIL contributed to how she developed professionally during the course. 
Drawing on the different instruments employed for data triangulation, the following categories emerged from Claudia's beliefs on content and language teaching, which were consistent with her teaching practices during the course. Claudia perceived language-driven CLIL as: 1) an authenticity-driven language teaching approach for both revising and introducing language items; 2) a useful approach with high English language proficiency learners; and 3) an approach for promoting interdisciplinary work among learners.

The first category drawn from Claudia's beliefs understood CLIL as an authenticity-driven language teaching approach for both revising and introducing language items. Claudia's lesson plans and delivery were built on learners' prior knowledge of structures and functions. Such prior knowledge was used to incorporate subject-specific phrases and terminology and new structures. For example, the Appendix shows how a lesson on search engine optimization was used to review imperatives and nouns together with the learners' prior knowledge about Google. On these foundations, Claudia introduced "going to" and subject-specific terminology for describing processes. In another lesson plan, she included aims such as:

- To review how to describe a general election using present passive voice.

- To introduce past passive voice to explain how women obtained the right to vote in Argentina.

When asked about the use of language-driven CLIL for reviewing and presenting new language, Claudia highlighted authenticity as a major element to achieve revision and presenting new items:

I think that language-driven CLIL can serve both purposes. For example, in the lesson about the history of Facebook, I made students review simple past to describe events, but then I used it to introduce cause and effect incorporating present perfect and specific items to verbalize cause and effect. But I could achieve this as I worked on authentic topics and authentic language. I've now realized that it is authenticity what makes the approach relevant as it acts as a cohesive element and there's meaning behind what the students can do with the language. (Extract 1)

This extract shows that, while some of the literature stresses the dual purpose of CLIL (e.g., Coyle et al., 2010), learning content and lan- 
guage together, as its main feature, Claudia stresses the authenticity element in the approach. Her belief of CLIL as an authenticity-driven approach for already known and new language is aligned with, for example, Pinner's $(2013,2019)$ view that authenticity supports motivational synergy between learners and teachers in CLIL because it makes learning relevant and connected to the world inside and outside formal education.

The second category (a useful approach with high English language proficiency learners) reflects Claudia's belief that, due to the use of authentic tasks and sources of input (e.g., a text, a website, a YouTube video), language-driven CLIL could be more fruitful with learners who have more advanced levels of English language proficiency:

I have to agree with the text we read from Ball. CLIL is not for everyone. I can't use it with elementary English language learners because it'd be very hard for them to understand the language and that'd cause problems with accessing the content. But with my older learners, whose level of English is higher, I see they can benefit more, they can learn more language, and above all, more content. (Extract 2)

Claudia's belief and decision to explore language-driven CLIL with older learners who had higher levels of ELP responds to Ball et al.'s (2015) recommendation that CLIL can be fruitful with learners with a stronger command of English in order to avoid content oversimplification. This belief and position are related to authenticity as a core element in CLIL. If authenticity of content, tasks, and materials, and by extension language, is a motivating factor for learning in CLIL, this feature cannot be affected because of limited ELP. Differently put, the more artificial and simplified the content and language, the less motivating the experience may become within a CLIL approach.

In relation to materials, Claudia selected sources of input that were clear in terms of content, but not in terms of language simplicity. In all her lessons, she used authentic materials designed for pedagogical and informative purposes, but not specifically designed for L2 learning. On this aspect, she reflected:

As I said before, authenticity is the queen in CLIL. Then, I choose videos or texts where the content is clear and appropriate for teenage learners. I can't treat the content as if they were primary school learners. The students need to be more proficient, more confident because we can't dumb down on content. (Extract 3) 
The relevance given to learners' needs reinforces Pimentel-Siqueira et al.'s (2018) view of the participatory nature that CLIL exhibits in Latin America. In this necessity to align CLIL with learners' trajectories, authenticity is a major motivational factor as content and materials are closely linked to the school curriculum, and therefore language learning becomes meaningful, as previously reported (e.g., Doiz, Lasagabaster, \& Sierra, 2014).

Finally, the third category, Claudia's beliefs of CLIL as an approach for promoting interdisciplinary work among learners, refers to how different curriculum areas can be coalesced through CLIL. Claudia noticed that language-driven CLIL lessons acted as a platform to synthesize the province curriculum regardless of the language in which content was acquired. For example, in one lesson about privacy and the Internet, she asked the learners to bring their classroom notes on a Spanish-medium lesson they had attended a week earlier with the Information and Communication Technologies teacher to make graphic organizers summarizing main ideas about the topic. She imbued her lessons with this cross-curricular characteristic, explaining that

It's about integration not just about content and language, but integration at a deeper level, among school subjects. So I think that through CLIL learners can do a lot of interdisciplinary work as they can draw on different subjects they've taken to complete a task or a project. It's really innovative to see the English lesson as a space in which learners can combine what they've learnt in Spanish with what they are learning in English. (Extract 4)

In this regard, interdisciplinarity acts as a didactic space for school integration. This feature assigned to CLIL reinforces authenticity, as it may be a reflection of learning, in its broadest sense, as social practice (Pinner, 2019). Human beings deploy a wide range of resources and tools to draw connections and their funds of knowledge, i.e., bodies of knowledge and skills people draw on to carry out different activities (Esteban-Guitart, 2014), do not strictly emanate from one source. Formal education, from a socio-cognitive perspective (Walsh \& Mann, 2019), aspires to provide learners with opportunities for curriculum integration. Thus, according to Claudia, language-driven CLIL can be that innovative approach that integrates content and languages in the curriculum. 


\section{Professional Development and Language-Driven CLIL}

The second research question sought to understand Claudia's experiences during the continuing professional development course she took on language-driven CLIL. The course was primarily anchored in teachers' professional practices in state secondary education. It included updated publications on CLIL such as books (e.g., Ball et al., 2015) and papers about CLIL in Latin America (e.g., Garzón-Díaz, 2018) to frame teachers' lesson plan design and implementation through peer and independent teaching.

The following categories emerged from Claudia's representations concerning her course experience: 1) teachers as research-informed materials developers, 2) structured learning as a platform for teacher reflection; 3) collaboration-independent work as a powerful sequence for theorizing practice; and 4) professional development as a motivational factor for engaging with language-driven CLIL.

The category teachers as research-informed materials developers refers to EFL teachers discovering and/or developing a new role in their teaching profession. Claudia, who had experience in developing worksheets and tasks prior to the course, felt that it had provided her with a sound framework for teacher-developed materials:

When I design the activities, and look for materials, I always have at hand the articles we've read, the investigations carried out by others concerning CLIL materials. I check the participating teachers' decisions and the authors' recommendations. And I see that I am comfortable with being a material developer, but I am comfortable because my materials draw on the research we've looked at, not just on my intuition or personal taste. (Extract 5)

The inclusion of reading material specifically addressing CLIL materials (e.g., Banegas, 2017) strengthened Claudia's identity as a materials developer, as there was a solid rationale she could draw on for responding to her learners' specific needs. The value assigned to the reading material is also a factor that contributed to the category considered below. This category also shows the importance of offering in-service courses that help teachers understand CLIL by developing materials (Banegas, 2016), as it is through tailored lesson plans and materials, as Ball et al. (2015) suggest, that in-service teacher education 
for CLIL becomes relevant and appropriate for the context in which it is implemented.

As described above, the course combined seminars held on Friday evenings with online support for lesson planning and materials development, peer teaching and classroom observation for formative feedback. These components unified structured learning, which Claudia understood as a platform for teacher reflection:

I think the clear structure of support, content, topics covered on each meeting, and the reading material on CLIL materials and lesson planning gave me the chance to organise my thinking, to reflect with a purpose, to benefit from my own reflection. I realized that I could link my own reflections with the material and concepts covered and my reflections were helpful to me because there was a clear structure for learning. (Extract 6)

In Claudia's view, structured learning, i.e., learning organized in any form, such as a course, structured and enhanced her reflections, as she could establish connections between her reflections, which may be conceptualized as internal theories, and external theories represented in the concepts and reading materials covered during the course, as suggested in Pérez-Cañado (2018c). Claudia's professional knowledge, i.e., knowledge of and about English together with research-informed and practice-based language teaching pedagogies in context (Johnson, 2009), was mobilized through reflection and readings on CLIL from a descriptive perspective. As Ball et al. (2015) discuss, CLIL teacher development should steer away from prescriptivism and offer instead tools that allow teachers to shape CLIL in ways that are compatible with their context.

In line with the category discussed above, collaboration-independent work as a powerful sequence for theorizing practice was another facet of Claudia's professional development supported by structured learning and her reflections. The course moved from collaborative lesson planning and delivery to individual lesson planning and teaching. This sequence, in Claudia's experience, allowed her to synthesize her reflections and support them with a pedagogical framework she developed as the course unfolded. For example, in her journal, two entries (my translation into English) reflect Claudia's development as she moved from collaboration and independent work: 
As we work together. I feel safe. Language-driven CLIL is new to me, and working together with a colleague for planning my lessons and materials and for teaching the lessons is helping me take care of everything myself. Now that I have to start planning alone, some CLIL concepts are clearer and I feel I can understand my teaching and make connections with the material and this is all because I've had peer support. (Extract 7)

Doing language-driven CLIL is not about applying the theory of others. I think it's recreating it. Like to me, authenticity, rather than integration is the most salient feature of CLIL. I started noticing that as Melania and I planned the lessons and had to design our activities and look for materials. And I became more sure about that as I continued reading and reflected on my lessons and saw that the major change in my teaching was because now authenticity was there. (Extract 8)

Finally, Claudia assessed the course from a motivational perspective. The category "professional development as a motivational factor for engaging with language-driven CLIL" represents Claudia's drive to continue with the course despite personal issues. For this category, professional development is understood as professional learning oriented towards improvement or change in effective practices and professional knowledge (Avidou-Ungar, 2016). The following extracts come from my notes (Extract 9) and interviews (Extract 10).

Claudia says that she enjoys doing the course because it energizes her as we're all working on the same approach. She adds that she comes meeting after meeting to share her achievements and concerns as she implements her lessons. (Extract 9)

The course, the nature and format of it, are a reason to do language-driven CLIL in my English classes. The course gives me the chance to learn and to share and to contribute and take ideas for my lessons. I love coming and I want to complete it so that I can carry on doing CLIL for the benefit of my students. Sometimes it's really hard as I've got to take care of my girl, no support, working extra hours to make ends meet, and I still do it because I feel energized when I come here (Extract 10).

The four categories identified in Claudia' experiences throughout the course suggest that professional development offers opportunities that can engage teachers in developing agency. For example, it is evident that Claudia's intrinsic motivation to broaden her skills and knowledge (Avidou-Ungar, 2016) helped her gain agency, as she was 
empowered by the course to take initiatives in her own teaching and development. As the course unfolded, she showed sophisticated levels of teacher reflection anchored in structured learning, which was characterized by effective readings and collaborative-individual work (Cirocki \& Farrell, 2017; Darling-Hammond et al., 2017; de Vries et al., 2013). The course, following Pistorio (2009) and Hillyard (2011), succeeded in providing Claudia with practical and theoretical tools for informed, effective, and context-responsive language-driven CLIL.

\section{Conclusion}

Despite the limited nature of this case study, we can say that Claudia's representations of her experiences suggests that a continuing professional development course with solid links between theory, reflection, and practice, supported by peers and a tutor specialized in CLIL, can help teachers understand and enact language-driven CLIL in a way that is context-responsive and aligned with learners' needs in meaningful opportunities for learning. The study also indicates that teachers, when supported over prolonged periods of time, can become reflective practitioners and start seeing themselves as materials developers or teachers who have moved away from a technical, mechanical view of instruction. They may develop, instead, a creative vein by designing their own materials. In the case of Claudia, by reflecting on her practices guided by the readings provided, she conceptualized authenticity in terms of language, content, tasks, and interdisciplinary work as an essential feature of language-driven CLIL. In this regard, she updated her professional knowledge and strengthened it with her own practice-based contributions. Claudia's experience reveals that professional development courses need to incorporate teachers' beliefs, past and present practices in context.

Preferably drawing on multiple case studies, future research should explore other professional development opportunities and examine whether which effects are sustained over time after collaboration and support have ceased. It is important that more instances of CLIL teacher education based in Latin America are socialized to provide a platform from which we can all learn. 


\section{Acknowledgements}

I would like to thank the anonymous reviewers and the journal's editorial team for their insight and support. Special thanks to Márcio Dalla Rosa for his translation of the abstract from Spanish to Portuguese.

\section{References}

Argudo, J., Abad, M., Fajardo-Dack, T., \& Cabrera, P. (2018). Analyzing a pre-service EFL program through the lenses of the CLIL approach at the University of Cuenca-Ecuador. Latin American Journal of Content and Language Integrated Learning, 11(1), 65-86. http://doi.org/10.5294/ laclil.2018.11.1.4

Avidov-Ungar, O. (2016). A model of professional development: Teachers' perceptions of their professional development. Teachers and Teaching, 22(6), 653-669. https://doi.org/10.1080/13540602.2016.1158955

Ball, P., Kelly, K., \& Clegg, J. (2015). Putting CLIL into practice. Oxford, UK: Oxford University Press.

Banegas, D. L. (2013). The integration of content and language as a driving force in the EFL lesson. In E. Ushioda (Ed.), International perspectives on motivation: Language learning and professional challenges (pp. 82-97). Basingstoke, UK: Palgrave Macmillan.

Banegas, D. L. (2016). Teachers develop CLIL materials in Argentina: A workshop experience. Latin American Journal of Content and Language Integrated Learning, 9(1), 17-36. http://dx.doi.org/10.5294/laclil.2016.9.1.2

Banegas, D. L. (2017). Teacher-developed materials for CLIL: Frameworks, sources, and activities. Asian EFL Journal, 19(3), 31-48. Retrieved from https://www.elejournals.com/asian-efl-journal/the-asian-efl-journal-quarterly-september-2017/

Banegas, D. L. (2018). Learning subject-specific content through ESP in a Geography teaching programme: An action research story in Argentina. English for Specific Purposes, 50(1), 1-13. http://dx.doi.org/10.1016/j. esp.2017.11.001

Banegas, D. L. (2020). (Ed.). Content knowledge in English language teacher education: International insights. London, UK/New York, NY: Bloomsbury. 
Banegas, D. L., Poole, P., \& Wade-Corrales, K. (in press). Latin American in CLIL: A critical review. Studies in Second Language Learning and Teaching.

Borg, S. (2006). Teacher cognition and language education. London, UK: Continuum.

Cirocki, A., \& Farrell, T. S. C. (2017). Reflective practice for professional development of TESOL practitioners. European Journal of Applied Linguistics and TEFL, 6(2), 5-24.

Coral, J., Lleixà, T., \& Ventura, C. (2018). Foreign language competence and content and language integrated learning in multilingual schools in Catalonia: An ex post facto study analysing the results of state key competences testing. International Journal of Bilingual Education and Bilingualism, 21(2), 139-150. http://dx.doi.org/10.1080/13670050.2016.1143445

Coyle, D., Hood, D., \& Marsh, D. (2010). Content and language integrated learning. Cambridge, UK: Cambridge University Press.

Darling-Hammond, L., Hyler, M. E., \& Gardner, M. (2017). Effective teacher professional development. Palo Alto, CA: Learning Policy Institute.

Darwin, S., \& Barahona, M. (2019). Can an outsider become an insider? Analysing the effect of action research in initial EFL teacher education programs. Educational Action Research, 27(5), 709-725. http://dx.doi.or g/10.1080/09650792.2018.1494616

de Vries, S., Jansen, E., \& van de Grift, J. (2013). Profiling teachers' continuing professional development and the relation with their beliefs about learning and teaching. Teaching and Teacher Education, 33(1), 78-89. http://dx.doi.org/10.1016/j.tate.2013.02.006

Doiz, A., Lasagabaster, D., \& Sierra, J. M. (2014). CLIL and motivation: The effect of individual and contextual variables. Language Learning Journal, 42(2), 209-224. http://dx.doi.org/10.1080/09571736.2014.889508

Esteban-Guitart, M. (2014). Funds of identity. In T. Teo (Ed.), Encyclopedia of critical psychology (pp. 752-757). New York, NY: Springer.

Garzón-Díaz, E. (2018). From cultural awareness to scientific citizenship: Implementing content and language integrated learning projects to connect environmental science and English in a state school in Colombia. International Journal of Bilingual Education and Bilingualism, http://dx.doi.org/10.1080/13670050.2018.1456512

Hawker, S., \& Kerr, C. (2016). Doing grounded theory. In E. Lyons \& A. Coyle (Eds.), Analysing qualitative data in psychology (pp. 147-159). London, UK/Thousand Oaks, CA: Sage. 
Hillyard, S. (2011). First steps in CLIL: Training the teachers. Latin American Journal of Content \& Language Integrated Learning, 4(2), 1-12. http://dx. doi.org/10.5294/laclil.2011.4.2.1

Ioannou Georgiou, S. (2012). Reviewing the puzzle of CLIL. ELT Journal, 66(4), 495-504. http://dx.doi.org/10.1093/elt/ccs047

Johnson, K. E. (2009). Second language teacher education: A sociocultural perspective. London, UK/New York, NY: Routledge.

Keogh, C. (2017). Using WhatsApp to create a space of language and content for students of international relations. Latin American Journal of Content and Language Integrated Learning, 10(1), 75-104. http://dx.doi. org/10.5294/laclil.2017.10.1.4

Llinares, A., \& Morton, T. (Eds.). (2017). Applied linguistics perspectives on CLIL. Amsterdam, The Netherlands/Philadelphia, PA: John Benjamins.

Mahan, R., Brevik, L. M., \& Ødegaard, M. (2018). Characterizing CLIL teaching: New insights from a lower secondary classroom. International Journal of Bilingual Education and Bilingualism. http://dx.doi.org/10.108 0/13670050.2018.1472206

Martínez-Agudo, J. (2019). Which instructional programme (EFL or CLIL) results in better oral communicative competence? Updated empirical evidence from a monolingual context. Linguistics and Education, 51(1), 69-78. http://dx.doi.org/10.1016/j.linged.2019.04.008

McDougald, J. (2015). Teachers' attitudes, perceptions and experiences in CLIL: A look at content and language. Colombian Applied Linguistic Journal, 17(1), 25-41. http://dx.doi.org/10.14483/udistrital.jour. calj.2015.1.a02

Merino, J. A., \& Lasagabaster, D. (2018). CLIL as a way to multilingualism. International Journal of Bilingual Education and Bilingualism, 21(1), 79-92. http://dx.doi.org/10.1080/13670050.2015.1128386

Navarro-Pablo, M., \& García-Jiménez, E. (2018). Are CLIL students more motivated? An analysis of affective factors and their relation to language attainment. Porta Linguarum, 29, 71-90. Retrieved from https:// dialnet.unirioja.es/servlet/articulo? codigo $=6273211$

Payne, S. (2016). Grounded theory. In E. Lyons \& A. Coyle (Eds.), Analysing qualitative data in psychology (pp. 119-146). London, UK/Thousand Oaks, CA: Sage.

Pérez-Cañado, M. L. (2018a). CLIL and pedagogical innovation: Fact or fiction? International Journal of Applied Linguistics, 1-22. http://dx.doi. org/10.1111/ijal.12208 
Pérez-Cañado, M. L. (2018b). Introduction. Porta Linguarum, 29, 5-7.

Pérez-Cañado, M. L. (2018c). Innovations and challenges in CLIL teacher training. Theory into Practice, 57(3), 1-10. http://dx.doi.org/10.1080/00 405841.2018.1492238

Pimentel-Siqueira, D. S., Landau, J., \& Albuquerque Paraná, R. (2018). Innovations and challenges in CLIL implementation in South America. Theory into Practice, 57(3), 196-203. http://dx.doi.org/10.1080/0040584 1.2018.1484033

Pinner, R. S. (2013). Authenticity and CLIL: Examining authenticity from an international CLIL perspective. International CLIL Research Journal, 2(1), 44-54.

Pinner, R. S. (2019). Authenticity and teacher-student motivational synergy: A narrative of language teaching. London, UK/New York, NY: Routledge.

Pistorio, M. I. (2009). Teacher training and competences for effective CLIL teaching in Argentina. Latin American Journal of Content \& Language Integrated Learning, 2(2), 37-43. Retrieved from https://laclil.unisabana. edu.co/index.php/LACLIL/article/view/2605

Ritchie, J., \& Lewis, J. (2003). Qualitative research practice: A guide for social science students and researchers. London, UK/New York, NY: Sage.

San Isidro, X. (2018). Innovations and challenges in CLIL implementation in Europe. Theory into Practice, 57(3), 185-195. http://dx.doi.org/10.108 0/00405841.2018.1484038

Walsh, S., \& Mann, S. (Eds.). (2019). The Routledge handbook of English language teacher education. London, UK/New York, NY: Routledge.

Yin, R. K. (2014). Case study research design and methods (5th ed.). Thousand Oaks, CA: Sage. 


\section{Appendix}

Lesson plan on search engine optimization

- Aims

- To talk about search engine optimization

- To include helpful vocabulary

- To talk about plans and processes using GOING TO

\begin{tabular}{|c|c|c|c|}
\hline & $\begin{array}{l}\text { LANGUAGE } \\
\text { FUNCTIONS }\end{array}$ & VOCABULARY & GRAMMAR \\
\hline REVISED & Giving directions & $\begin{array}{c}\text { Nouns (count/ } \\
\text { uncount) }\end{array}$ & $\begin{array}{c}\text { Simple Past } \\
\text { Imperatives }\end{array}$ \\
\hline NEW & $\begin{array}{c}\text { Summarising, } \\
\text { describing a process }\end{array}$ & $\begin{array}{c}\text { SEO-related } \\
\text { terms }\end{array}$ & Going to (future) \\
\hline
\end{tabular}

- Warm-up

Activity 1: Teacher: In ICT, what's SEO? In this lesson we'll take a look at that. Orally, students guess what it may mean:

SEO: 1. search engine operation, 2. search engine optimisation, 3. system electronic organization.

Activity 2: Complete this definition with words from the box.

Search engine optimization (SEO) is the practice of increasing the quantity and of traffic to your through organic search engine The primary of SEO is to drive more unpaid useful traffic to a site that converts into sales.

(BOX: website, quality, results, capacity, modern, function).

- Development (break-down of activities)

Teacher: Let's take a closer look at SEO.

Activity 3: Look at the following extracts. What does each talk about? Choose from the options below: organic results, SEO functions, quality of traffic, quantity of traffic.

1. You want to attract visitors who are genuinely interested in products that you offer.

2. Once you have the right people clicking through from those search engine results pages (SERPs), more traffic is better.

3. This is any traffic that you don't have to pay for. 
Activity 4: Let's watch a video about how SEO works. The person who speaks is Matt Cuts and he is an engineer on the Quality Group on Google. VIDEO https://www.youtube.com/watch?v=BNHR6IQJGZs\&t=1s

a. Before you start watching, what key concepts do you think he is going to mention and why?

b. While watching. Complete with the missing information you get from the video.

1. "When you do a Google search, you aren't actually searching the web.

2. "Spiders start by fetching. then they follow the links and follow all the links and so on until we've been next to a pretty big chunk of the web."

3. Describe the process of a search according to what you hear.

4. How does Google decide what documents you really want? Post-watching:

1. Provide examples of the questions Google asks in your search.

2. How long does it take to get the information you want after you submit the search?

3. What things does Matt mention in relation to his own search results?

4. Almost at the end of the video, he mentions something that is included in the search. What is it and why is it so important?

Activity 5: In pairs, ask and answer.

What do you use Google for?

When you want to find something, what words do you use?

When you get different hits, which pages do you choose to read?

Activity 6: Complete this table in pairs

\begin{tabular}{|l|l|}
\hline To find out about... & we're going to type key words like... \\
\hline wind energy & \\
\hline the life of a famous scientist & \\
\hline new devices in the market & \\
\hline
\end{tabular}

After this, we draw students' attention to the GOING TO structures. With their help, we introduce the function and rules of GOING TO. 
Activity 7: Complete.

I'm going to...

It's going to...

Google engineers are going to...

- Closure: Draw a word cloud with key vocab learnt today. 